Vol. 4, No. 3, 2019

\title{
EVALUATION OF THE DEGREE OF ENVIRONMENTAL HAZARD FROM ENVIRONMENTAL POLLUTION IN THE AREA OF POULTRY FARMS IMPACT
}

\author{
Maria Kanda, Myroslav Malovanyy, Ivan Tymchuk, Zoryana Odnorih \\ Lviv Polytechnic National University, \\ Institute of Sustainable Development, \\ Department of Ecology and Sustainable, Environmental Management \\ 12, S. Bandery Str., Lviv, 79013, Ukraine \\ 27kandam@gmail.com,myroslav.mal@gmail.com, \\ i.s.tymchuk@gmail.com,odnorigzor@gmail.com
}

https://doi.org/10.23939/ep2019.03.161

Received: 12.08.2019

(C) Kanda M., Malovanyy M., Tymchuk I., Odnorih Z., 2019

\begin{abstract}
This article identifies the sources of environmental hazard in the area of poultry farms impact. The analysis of the nature and scope of pollution is made. Developmental specifics of poultry farming in Ukraine are considered. The prospects of the utilization of natural sorbents in the composition of bedding in order to mitigate pollution of the environment with ammonia and ammonium compounds are studied. The scope of reduction of environmental hazard as a result of the utilisation of natural dispersive sorbents in poultry farming is analysed.
\end{abstract}

Key words: source of environmental hazard, natural sorbent, poultry farming, bedding.

\section{Introduction}

Assessments [1] show that farming generates up to $20 \%$ of overall pollution emissions into all the components of the environment: atmosphere, hydrosphere and lithosphere. Poultry farming is considered to be the most sever environmental polluter of all the agricultural producers [3]. In [2] an emphasis is put on the sources of environmental hazard, related to poultry farms in Ukraine, which are pertinent to the generation of solid wastes causing further pollution of the atmosphere and hydrosphere. These sources together with the approximate waste output (with the consideration of specialised farms only) are provided below:

1. Droppings with natural moisture content $-5.2 \mathrm{mln}$;
2. Birds that died -50 ths $\mathrm{t}$;

3. Bird slaughter waste -210 ths $t$;

4. Incubation waste -12 ths $t$.

The second, third and fourth types of wastes require special measures and processes for their disposal, implementation of which is mandatory for each poultry farm, and operation of farms without them is unacceptable. Therefore, we did not take them into account as the sources of environmental hazard in operation of poultry farms. According to the information of the authors [2], the most massive wastes are droppings, which are a metabolic by-product of birds. We did not consider micro- and macrobiological pollution of the environment (microorganisms, helminths, flies, etc.), which are secondary pollutants, and the intensity of their impact would be significantly reduced with successful solving the task of minimizing environmental hazard caused by poultry droppings. This research considers chicken droppings as the main cause of environmental hazard in the area of impact of poultry farms.

Based on the assumptions above, the sources of environmental hazard are closely related to places of localisation and routes of transportation of poultry droppings. Waste accumulation greatly depends on the farming technology and equipment used to maintain this process [2]. These indicators also influence the moisture content of wastes, which can vary from 82-98 \% (when using scraping system for droppings removal from cage batteries) to 55-65\% (when using belt conveyors) and to $20-50 \%$ (when using ventilated belt conveyors $[3,4]$ ). 
Thus, we can outline 3 potential sources of environmental hazard (SEH) caused by poultry droppings at a poultry farm, which are closely related to the sites of their generation, transportation and localisation. In the sequence of development of the technological process at a poultry farm, these SEH may be presented by the following diagram (Fig. 1).
Based on the diagram in Fig.1, we can highlight the following SEH:

1. SEH 1 - birds keeping site (generation of droppings).

2. SEH 2 - droppings transportation system.

3. SEH 3 - droppings storage (localisation) sites.

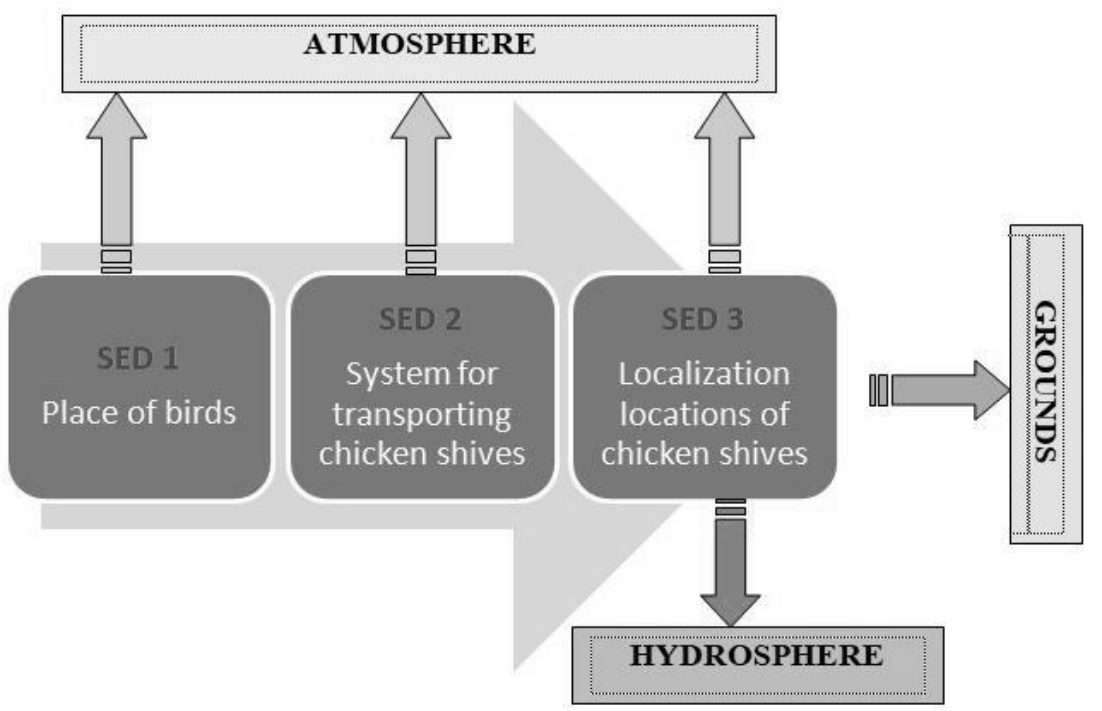

Fig. 1. Diagram of SED at a poultry farm

According to the data [5-7], the average loss of separate components of droppings in the process of their generation, transportation and storage makes up around $10 \%$, and as to the elements like nitrogen, it is up to 20$50 \%$. Most of nitrogen converts into ammonium form and contaminates the atmosphere and hydrosphere.

As to the first two sources of environmental hazard, basically they are characterised by the pollution of the atmosphere with ammonia (there is no direct pollution of the hydrosphere from these sources). According to the data [2], the volumes of ventilation gasses from one typical poultry house, where broilers are raised or egglaying chicken are kept, are as follows:

- in summer -200 to 500 ths $\mathrm{m}^{3} /$ hour of polluted air;

in winter -10 to 50 ths $\mathrm{m}^{3} /$ hour of polluted air.

The concentration of contaminants in these gases is as follows:

- ammonia - (3-20) $\mathrm{mg} / \mathrm{m}^{3}$;

- hydrogen sulphide - (1-3) $\mathrm{mg} / \mathrm{m}^{3}$;

$-\mathrm{CO}_{2}-(0.1-0.3) \%$;

- Dust (3-5) $\mathrm{mg} / \mathrm{m}^{3}$;

- microbial bodies - (70 000-900 000) m.b./m

Ammonia and hydrogen sulphide are released into gas medium from droppings and bedding as a result of the biodegradation of organic matters. Ammonia and carbon dioxide are also produced from uric acid due to its interaction with microflora (uric acid is a primary product of degradation of poultry protein [8]). Providing that the standards on microclimate and bird-holding density in a poultry house are met, each hour $1 \mathrm{~m}^{2}$ of bedding releases [9]:

- ammonia - $25 \mathrm{mg}$;

- hydrogen sulphide - $15 \mathrm{mg}$;

- carbon dioxide $-8 \mathrm{mg}$.

In case of litter-free method of poultry raising, $1 \mathrm{~m}^{2}$ of floor in a poultry house covered with droppings generates [9]:

- ammonia - $8 \mathrm{mg}$;

- hydrogen sulphide $-5 \mathrm{mg}$;

- carbon dioxide $-5 \mathrm{mg}$.

As to the $3^{\text {rd }}$ source of environmental hazard droppings storage (localisation) sites, it is prone to contaminate all the components of the environment: atmosphere, hydrosphere and lithosphere.

\section{Analysis of developmental trend and localisation of poultry farming in Ukraine}

Poultry farming, rapidly developing in Ukraine in recent years, is characterised by a dynamic developmental trend and production of high-quality food products. 
Today, poultry farming is one of the most prioritised areas of cattle farming. Rapid development of poultry farming in Ukraine is accompanied by the increase in production of eggs and meat and enlargement of the poultry stock. First of all, this is explained by the growth of demand of food companies and population for poultry products because of their relative cheapness as compared to other types of meat. It turned out that the poultry industry was capable of prompt adaptation to the market conditions due to its mobility under the transformation of the agroindustrial complex.

Currently, development of the poultry industry is induced by high-tech companies, which have proved their developmental innovativeness under the market conditions. By increasing performance while reducing the feeding costs, these companies rapidly raise the product output [10].

Innovative organisational strategies of efficient development of poultry farming under the established market are based on principles of cooperation, reasonable localisation based on the analysis and with the consideration of climatic natural conditions, diversification of agricultural production, intra-industry specification, integration, and rational concentration and optimisation of production.

The basic approach to ensuring the dynamic development of poultry farming implies engagement of research and development products in the form of design and process solutions and technological means of their application, as well as engagement of innovative lowcost energy- and resource-saving automated technologies in production and processing of poultry products. This development will benefit from the implementation of international food quality and safety standards and improvement of the quality of breeding resources.

As to localisation of poultry farms on the territory of Ukraine, there are few industry leaders holding up to $70 \%$ of the poultry stock in Ukraine. $6-13 \%$ of overall poultry stock are localised in the Kyiv, Cherkasy, Vinnytsia, Kherson and Dnipropetrovsk Regions [10].

Poultry production is concentrated in the foreststeppe zone. Due to the rapid return on investment in poultry production, the pace of investment growth tends to increase sharply. This contributes to the quick increase in the number of large up-to-date poultry farms, and the establishment and development of powerful vertical-integrated companies. In 2017, poultry production in the forest-steppe zone reached 857.68 ths $\mathrm{t}$ of meat, making up $71 \%$ of overall production output in Ukraine. The poultry production output in the steppe zone was $20.5 \%$, and in Polissia it was $8.5 \%$. The leaders of poultry meat production are the Cherkasy (23\%), Vinnytsia (18.9\%), Dnipro (14\%) and Kyiv
(13.6\%) Regions. The Volyn Region is also among the leaders with its share of $5.8 \%$ of the total poultry meat output.

The developmental trend of egg production in Ukraine does not show the tendency of rapid growth. According to the information published by ProConsulting, the egg market in Ukraine decreased by $24 \%$ for the five years starting from 2013. Inconsiderable revival of the production in 2017 was mitigated by the export growth. The domestic consumption turned out to be at the level of 2016 . The decrease in production is explained by the increase in cost, the decrease in the purchasing capacity of the population, and temporary loss of the territory enclosing both producers and consumers. However, according to the data of the Association of Poultry Farmers of Ukraine, the production of eggs at poultry farms of Ukraine from January to March of 2018 was $2147.8 \mathrm{mln}$ units as compared to $2064.8 \mathrm{mln}$ from January to March of 2017.

Over 2 bln of eggs, i. e. (2.7 bln eggs) are produced by the Kyiv Region (13.8\%), which appears to be the unequivocal leader. The Kherson, Donetsk and Khmelnytsk Regions together produce $24.7 \%$ of eggs. The share of these regions varies from $8.4 \%$ to $9.8 \%$. The Dnipro and Kharkiv Regions produce $5.3 \%$ of the Ukrainian egg output each [10].

By 2016 the poultry stock in Ukraine was $213.2 \mathrm{mln}$ birds. In 2017 the poultry stock was $205.1 \mathrm{mln}$ birds, i. e. it reduced by $3.9 \%$.

\section{Experimental part}

A diagram of the experimental installation used for conducting the study aimed at determination of the optimal conditions and a propepr ratio of the components in a mixture of natural mineral sorbets and poultry droppings is shown in Fig. 2. The study was performed using an installation consisting of a reaction flask with Atinan At-A850 compressor connected and Drechsel bottles. $10 \mathrm{ml}$ of sulphuric acid $\left(0.5 \mathrm{~mol} / \mathrm{dm}^{3}\right)$, 5 drops of methyl red and $100 \mathrm{ml}$ of distilled water were put into the Drechsel bottles. After certain time intervals (each 5, 15, 30, 60 minutes), one Drechsel bottle was replaced with another, and the amount of sulphuric acid taken for the neutralisation of distilled ammonia was analysed by backward titration using sodium hydroxide solution with the concentration of $1 \mathrm{~mol} / \mathrm{dm}^{3}(1 \mathrm{n})$.

Sample mixtures were equilibrated for several hours. This time period was sufficient to determine the steady-state concentration of ammonia in sorbent and air medium of the flask. Based on the study results, we calculated the weight of ammonia absorbed by sorbent or the study composition. 


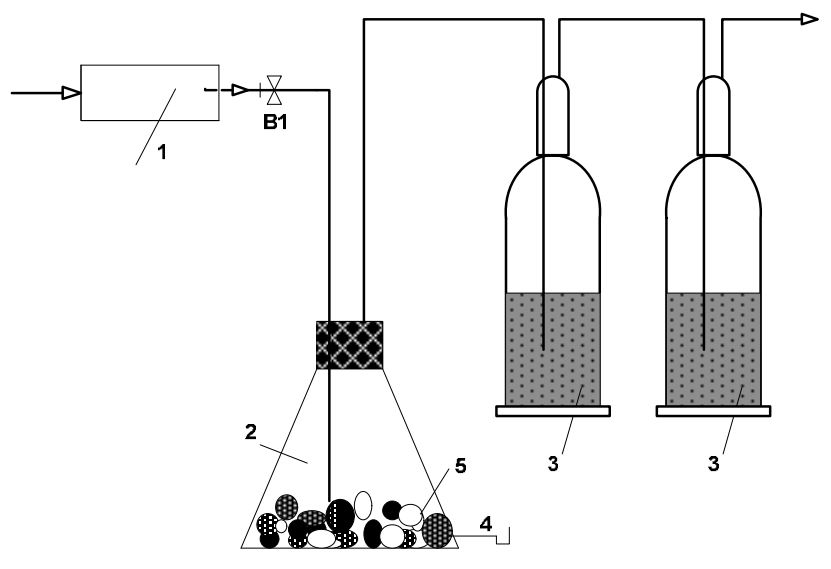

Fig. 2. Diagram of experimental installation:

1 - compressor; 2 - flask; 3 - Drechsel bottle;

4 - fragment of litter sample; 5 - natural sorbent; B1 - valve

Kinetics of the ammonia adsorption process was studied as follows: $250 \mathrm{~cm}^{3}$ flasks were filled with $10 \mathrm{~g}$ batches of air-dry sorbent and $5 \mathrm{~cm}^{3}$ of ammonium solution ( $25 \%$ wt.). The purpose of the experiments was to determine and compare the capacity of natural sorbents for absorbing ammonia from $5 \mathrm{~cm}^{3}$ of ammonium solution $(25 \%)$ in different time range. $250 \mathrm{~cm}^{3}$ flasks containing sample mixtures were preliminarily equilibrated for 0.5 hour (flasks $1-3$ ) and 7 days (4-6 flasks). The ammonia content in the fluid mixture was determined by weight titrimetric analysis.

\section{Results of investigation}

Environmental hazard in the area of impact of poultry localisation (poultry farms, complexes, private farms) was assessed by analysing the sources of environmental hazard one by one (Fig. 1). The first source SEH 1 - birds' localisation site, is the major one, because the stage of birds keeping is associated with the emergence of ecological hazard caused by poultry droppings, which further extends to the process of transportation (SEH 2) and storage (SEH 3) of droppings. In order to assess the amount of ammonia released by SEH 1, it is necessary to take into account a number of birds kept per year, a method of keeping (i.e. litter or litter-free method for broilers; cage batteries, floor housing, colony cages, multilevel floor, free-range keeping of egg-laying chicken, etc.), a sequence of keeping cycles and cycles of preventive maintenance of premises, a type of birds (meat poultry, laying chicken), season conditions and microclimate of birds housing, etc. Certainly, it is difficult to estimate these factors throughout the country, especially in the absence of statistical information specially collected by specific indicators. We consider that in order to assess the level of environmental hazard in the area of impact of birds' localisation sites, it is reasonable to use averaged indicators, which allow to evaluate the effect of actions on the minimisation of this environental hazard proposed in the thesis.

As to ammonia emission from $1 \mathrm{~m}^{2}$ of bedding, it makes up $25 \mathrm{mg} /$ hour [7]. For litter-free droppings of the natural moisture content, ammonia emission is $8 \mathrm{mg}$ /hour [7] from $1 \mathrm{~m}^{2}$ of bedding. Since the litter method of keeping is the most common in Ukraine, in order to assess environmental hazard we will use ammonia emission of $25 \mathrm{mg} /$ hour from $1 \mathrm{~m}^{2}$. There are different indicators for the norm of bird-keeping density in poultry houses for different types of chicken. For rearing meat-type chicken at the age of 1-20 weeks it is 9 , at the age of $21-26$ weeks it is $4-8$, for parental stock it is 4-5. Considering that, it is impossible to determine the relation between different types of the poultry stock within Ukraine; in addition it varies throughout the year. We took the average norm of bird-keeping density in poultry houses of Ukraine equal to 7 . Thus, the total area of bedding in Ukraine (taking into account the poultry stock of Ukraine based on the data of 2017) is $213200000 / 7=30457000 \mathrm{~m}^{2}$, and hourly total ammonia emission in Ukraine is $30457000 \times 25=761425000 \mathrm{mg}$ or $761.425 \mathrm{~kg}$. Daily ammonia emission is $28.27 \mathrm{t}$, and annual emission is $6670 \mathrm{t}$.

It is even more difficult to analyse the scope of contamination from SEH 2 and SEH 3, because in this case it is necessary to consider individual conditions of droppings transportation and storage as well as the adopted strategy of its utilisation. Therefore, we believe it is reasonable to stick only to the identification of these sources of environmental hazard and development of recommendations on their minimisation.

The prospective way to minimise environmental hazard from SEH 1 is to apply sorbents to the bedding composition, which adsorb part of ammonia released by chicken droppings [11, 13]. This will ensure the reduction of ammonia emissions polluting the atmosphere as a result of its adsorption by adsorbents. At the same time, these adsorbents with adsorbed ammonia can be used as an efficient long-acting nitrogenous fertiliser.

We investigated the prospectivity of palygorskite and clinoptilolite application in the composition of bedding in order to reduce the environmental pollution with ammonia. It was necessary to determine the optimal ratio in order to derive beneficial properties from both sorbents. Their application to poultry droppings will contribute to efficient reduction of the moisture content and adsorption of ammonia from droppings. This will help to fix nitrogen in the exchangeable form and reduce its loss. 
We conducted experimental studies in order to determine the optimal ratio of mixture of natural mineral sorbents for efficient absorption of ammonia. For this purpose, we prepared batches in the following weighing ratios: $0 \mathrm{~g}$ of palygorskite : $10 \mathrm{~g}$ of clinoptilolite; $0 \mathrm{~g}$ of clinoptilolite : $10 \mathrm{~g}$ of palygorskite; $1.5: 8.5 ; 3: 7 ; 5: 5$; $7: 3 ; 8.5: 1.5 \mathrm{~g}$ of the sorbents, respectively. The studies were conducted by the method described above and under isothermal conditions $\left(\mathrm{T}=20^{\circ} \mathrm{C}\right)$. Constant temperature conditions of the process were maintained using a thermostat. According to the results of the study, the highest capacity was shown by the composition at the ratio of $1: 1$ (5 $\mathrm{g}$ of clinoptilolite : $5 \mathrm{~g}$ of palygorskite).

Further, we had to determine the ratio between the mixture of the sorbents and poultry droppings. For this purpose, we prepared batches in the weighing ratios of $10 \mathrm{~g}$ of the mixture : $50 \mathrm{~g}$ of droppings $(1: 5) ; 10: 60$ $(1: 6) ; 1: 5.5 ; 1: 4 ; 1: 3.5 ; 1: 3 ; 20$ : 50 (1:2,5), respectively. The study results are presented in Table 1.

Table 1

\section{Determination of the optimal ratio of mixture of the natural dispersive sorbents to litter}

\begin{tabular}{|c|c|}
\hline $\begin{array}{c}\text { Ratio of palygorskite }+ \\
\text { clinoptilolite }(1: 1) \text { mixture to } \\
\text { litter }\end{array}$ & $\begin{array}{c}\text { Weight of absorbed } \\
\text { ammonia, mmol/g of } \\
\text { sorbents } \cdot 10^{-1}\end{array}$ \\
\hline $1: 6$ & 0.92 \\
\hline $1: 5.5$ & 1.3 \\
\hline $1: 5$ & 1.56 \\
\hline $1: 4$ & 1.5 \\
\hline $1: 3.5$ & 1.1 \\
\hline $1: 3$ & 0.84 \\
\hline $1: 2.5$ & 0.34 \\
\hline
\end{tabular}

According to Table 1, the highest capacity for ammonia adsorption was shown by the composition "sorbents : chicken droppings" at the ratio of 1:5. It makes $1.56 \mathrm{mmol} / \mathrm{g}$ of sorbents $\cdot 10^{-1}$.

According to the information provided in [9], the average volumetric weight of straw in litter is 100 $\mathrm{kg} / \mathrm{m}^{3}$ and the remaining types of litter (sphagnum turf, sawdust, chips. sunflower hull, ground sonflower stems, etc.) are $150 \mathrm{~kg} / \mathrm{m}^{3}$. The volumetric weight of litter without adding adsorbents, assumed for calculation purposes, is $150 \mathrm{~kg} / \mathrm{m}^{3}$. As to the bedding thickness, it is defined based on a type of birds raised on it. In particular, according to [9], the thickness of a bedding layer for egg-laying chickens, meat and egg breeds and replacement chickens must be $15 \mathrm{~cm}$, while for meat and replacement chickens it must be $20 \mathrm{~cm}$. For calculation purposes we take the bedding thickness of $0.2 \mathrm{~m}$. Then, the weight of $1 \mathrm{~m}^{2}$ of bedding is $30 \mathrm{~kg}$. In case of adding the sorbents to bedding at the ratio of palygorskite + clinoptilolite (1:1) mixture to poultry droppings $1: 5$, their weight per $1 \mathrm{~m}^{2}$ of bedding is $7.5 \mathrm{~kg}$.

For different types of birds the cycle of birds keeping without changing bedding is different. Namely, for replacement chicken it is 17-21 weeks (not more than 19), for young birds raised for meat it is 9-10 weeks. For calculation purposes, we take the keeping cycle of 10 weeks. Then, $1 \mathrm{~m}^{2}$ of bedding without adding adsorbents per 1 cycle would release $25 \times 10 \times 7 \times 24=42000 \mathrm{mg}$ or $42 \mathrm{~g}$ of $\mathrm{NH}_{3}$. In case of adding the sorbents to bedding at the defined optimal ratio, they adsorb $0.186 \times 17 \times 7500=23715 \mathrm{mg}$ or $23.7 \mathrm{~g}$. This is more than half of total released ammonia. Given that some amount (up to $15 \%$ of released ammonia) is adsorbed by bedding material, the overall amount of adsorbed ammonia will be about $60 \%$ (which correlates with the data of other researchers [9]). The performed calculations are shown in Fig. 3. The figure provided shows that with the application of the adsorbents to the bedding composition at the defined optimal ratio the amount of ammonia polluting the atmosphere drops almost 4 times.

Calculation of the overall amount of ammonia adsorbed when adding the adsorbents to bedding in Ukraine is of gret interest. Using the relations obtained above, we performed calculations based on the data on total ammonia emissions from poultry farms of Ukraine for one year, estimated above. These calculations are shown in Fig. 4. The data provided in Fig. 4 indicate a significant reduction in the degree of environmental hazard with the implementation of the proposed measure application of the adsorbents at the defined optimal ratio to the bedding composition.

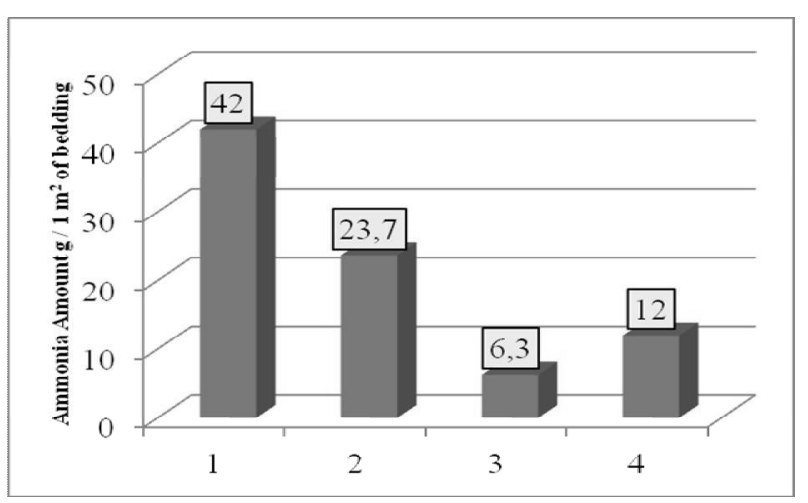

Fig. 3. Visualisation of the ammonia amount released from $1 \mathrm{~m}^{2}$ of bedding per 1 bird-raising cycle:

1 - total released ammonia; 2 - adsorbed by adsorbent; 3 - adsorbed by bedding material; 4 - polluted the atmosphere 


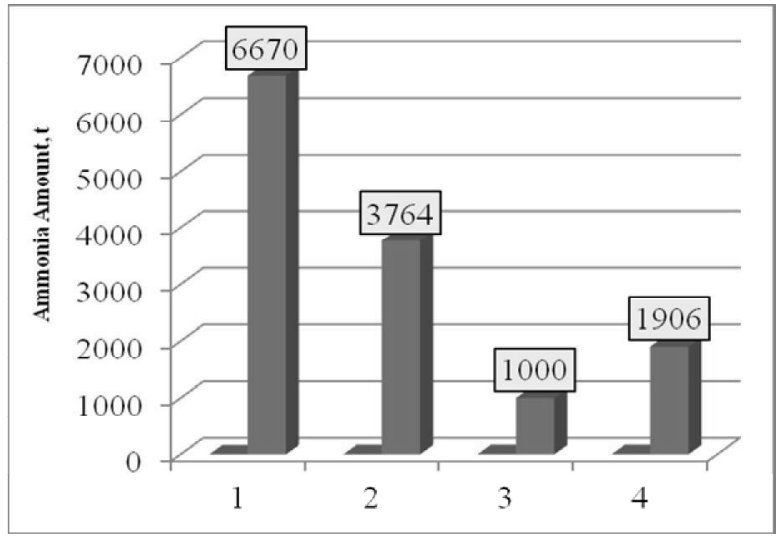

Fig. 4. Visualisation of the ammonia amount released for one year from poultry farms of Ukraine: 1 - total released ammonia; 2 - adsorbed by adsorbent; 3 - adsorbed by bedding material; 4 - polluted the atmosphere

\section{Conclusion}

We identified the sources of environmental hazard in the area of impact of poultry farms in Ukraine. It has been found that there are 3 potential sources of environmental hazard caused by poultry droppings at a poultry farm, which are closely related to the places of their generation, transportation and localisation. Poultry farms - places of generation of poultry droppings that release contamination into the atmosphere, hydrosphere and lithosphere are the detrimental source of environmental hazard. We conducted the analysis of the developmental trend and localisation of poultry farming in Ukraine. It has been found that nowadays poultry farming is one of the most prioritised areas of cattle farming. Rapid development of poultry farming in Ukraine is accompanied by the increase in the production of eggs and meat and the enlargement of the poultry stock. Development of the poultry industry is induced by high-tech companies, which have proven their developmental innovativeness under the market conditions. Most of the poultry stock is localised in the Kyiv, Cherkasy, Vinnytsia, Kherson and Dnipropetrovsk Regions. Some decrease in production is explained by the increase in cost, the decrease in the purchasing capacity of the population, and temporary loss of the territories enclosing both producers and consumers.

Assessment of environmental hazard in the area of impact of poultry farms in Ukraine shows that total emission of ammonia within Ukraine is $761.425 \mathrm{~kg}$ per hour, $28.27 \mathrm{t}$ per day and $6670 \mathrm{t}$ per year. It has been estimated that the introduction of sorbents in the bedding composition at the ratio of mixture of palygorskite + clinoptilolite (1:1) and poultry droppings to bedding $-1: 5$ allows the adsorption of $84 \%$ of total ammonia emitted by poultry droppings, i. e. after the introduction of adsorbents in the bedding at the defined optimal ratio, the amount of ammonia released to the ventilation system decreases 6.3 times.

\section{References}

[1] Tsarenko A. M.: Ekonomicheskie problemyi proizvodstva ekologicheski chistoy agropromyishlennoy produktsii (teoriya i praktika). Agrarna nauka, KiYiv, 1998. 256 s. (in Russian)

[2] Melnyk V. O.: Ekolohichni problemy suchasnoho ptakhivnytstva, Ptakhivnytstvo: mizhvid. temat. nauk. zb. /IP UAAN. Kharkiv, 2009. Vyp. 63. S. 1-15. (in Ukrainian)

[3] Peshel Zh.: Sistemyi uborki pometa $\mathrm{s}$ aeratsiey. Ptitsevodstvo. 1995. \# 2. S. 36 -37. (in Russian)

[4] Savostianova K. V., Melnyk V. O.: Pidsushuvannia poslidu na strichkovykh transporterakh klitkovykh batarei dlia utrymannia kurei-nesuchok. Ptakhivnytstvo: mizhvid. temat. nauk. zb. /IP UAAN. Kharkiv, 2007. Vyp. 59. S. 138-145. (in Ukrainian)

[5] Podgotovka, pererabotka pometa na ptitsefabrikah i ispolzovanie ego v zemledelii: [nauchno-prakticheskie rekomendatsii] / pod obsch. red. V. I. Fisinina (Ed.). Sergiev Posad, 2001. 108 s. (in Russian)

[6] Burnett W. E., Dondero N. C.: Microbiological and chemical changes in poultry manure associated with decomposition and odour generation. Animal Waste Management: Proceedings of Cornell University Conference of Agriculture Waste Management. 1969. P. 271-274.

[7] Nahm K. H.: Factors influencing nitrogen mineralization during poultry bedding composting and calculations for available nitrogen. World's poultry science journal. 2005. Vol. 61. P. 238-255.

[8] Colanbeen M. Neukermans G.: Invloed van strooisel en NH3 op de produktieresultaten bij slachtpluimvee: literatuuroverzicht. Rev. Agr. 1990. Vol. 43, No. 2. P. 227-240.

[9] Pidpryiemstva ptakhivnytstva: Vidomchi normy tekhnolohichnoho proektuvannia VNTP-APK-04.05. Kyiv: Minahropolityky Ukrainy, 2005. 90 s. (Normatyvnyi dokument Minahropolityky Ukrainy). (in Ukrainian)

[10] Bezhenar I.M., Vasiuta T.M.: Stan ta perspektyvy rozvytku ptakhivnytstva v Ukraini. Ahrosvit, \#18, 2015. S. 41-51. (in Ukrainian)

[11] Miner J. R.: Finely ground zeolite as an odour control additive immediately prior to sprinkler application of liquid dairy manure. Proc. of the Int. Symp. on Ammonia and Odour Emissions from Animal Production., 6-10 Oct. 1997. Vinkeloord, the Netherlands. 1997. P. 717-720.

[12] Schntider A. F. et al.: Natural zeolites in diet or litter of broilers. British Poultry Science. 2016. Vol. 57, No. 2. P. 257-263.

[13] Sarica M.: The Effects of Evaluated Litter with Natural Zeolite on the Broiler Performance and Environmental Conditions of Broiler Houses. World Poultry Congress. Istanbul : Turkey, 2004. 